\title{
Occurrence of e antigen in acute hepatitis B
}

\author{
PATRICIA E. GIBSON AND KOKILA RUPARELIA \\ From the Virus Reference Laboratory, Central Public Health Laboratory, Colindale Avenue, London \\ NW9 5HT, UK
}

SUMMARY The occurrence of e antigen in 44 patients with acute hepatitis B was studied in order to determine if e was related to the outcome of the illness. In $13.6 \%$ of cases e was detected, and in none of these did the carrier state develop. The HBsAg carrier state developed in $4.6 \%$ of the patients and in none of these was e antigen detected. Anti-e was detected in only three cases. Only in the very early acute phase of illness e was detected and the time serum samples were taken for the detection of e was considered to be very significant. The occurrence of e was not found to affect the duration of HBs antigenaemia in those patients who recovered completely.

In 1972 Magnius and Espmark identified a new antigen in the sera of some individuals who were carriers of hepatitis B antigen. It was suggested by them that ' $e$ ' might be an indicator of infectivity. Nielsen et al. (1974) subsequently suggested that $\mathrm{e}$ antigen might be of some prognostic value. They thought that when e was present in acute hepatitis, chronic liver disease might develop rather than full recovery. Norkrans et al. (1976) have supported this hypothesis and have indicated that cases of acute hepatitis B which have detectable e antigen have HBs antigenaemia for significantly longer periods than those with no e antigen.

This report describes the occurrence of $e$ and anti-e in a series of cases of acute hepatitis B and relates them to the outcome of these illnesses.

\section{Patients and methods}

The sera from 44 patients with acute hepatitis B were examined for HBsAg and e antigen and antibody at intervals during the course of the infection until either the patient had recovered completely and there was no detectable HBsAg present in the blood or until it seemed that a carrier state had developed. Only those patients whose initial serum sample was taken within one month of the onset of jaundice were included in the study. The duration of antigenaemia was taken as the midpoint between the last HBsAg positive sample and the first $\mathrm{HBsAg}$ negative sample.

HBsAg was detected by IEOP and RIA (Ausria II). e Antigen and antibodies were detected by

Received for publication 14 March 1977 immunodiffusion; e antigen and antibody reference sera were kindly supplied by $\mathrm{Dr}$ L. $O$. Magnius (Stockholm) and Dr J. O. Nielsen (Copenhagen).

\section{Results}

Table 1 gives the findings for e antigen. Although two patients are listed as having become carriers of HBsAg following acute hepatitis, this is not a certainty. The last available specimen from one of these patients was only three months after the onset of hepatitis and although this specimen was strongly positive (detectable by IEOP) for $\mathrm{HBsAg}$, it is possible he could have eventually cleared. However, the other patient was still a carrier at seven months after the onset of hepatitis and at this point anti-e was first detected. No further specimens were received from this patient.

Anti-e was detected in only three cases of acute hepatitis B (Table 2). In one of the patients who had previously had detectable e antigen, anti-e was detected in the first HBsAg negative specimen three weeks after the onset of jaundice. e Antigen had been detected in this patient only in the first HBsAg positive specimen just before the development of jaundice. Anti-e developed in the other patient, who recovered completely, only in the last $\mathrm{HBs} A \mathrm{~g}$ positive specimen.

As shown in Table 3, it can be seen that in all six cases of acute hepatitis $B$, where e antigen was detected, it was seen within the first week following the onset of jaundice. In one of these cases it was seen even before the appearance of jaundice. In five of these patients it was detected only in the first serum 
sample available. In the sixth patient it was detected in the first two serum samples, both of which were taken in the first week of jaundice. Of the 44 patients studied, only in 15 was the first available serum sample taken within the first week of jaundice, and all six positive cases were in this group (40\%).

Table 4 indicates that the presence of e antigen in the acute phase of illness was not related to the duration of HBs antigenaemia in those patients who recovered completely.

Table 1 Occurrence of $e$ antigen in 44 cases of acute hepatitis $B$

\begin{tabular}{llcc}
\hline Outcome & e Antigen & Number & Percentage \\
\hline Complete & + & 6 & 13.6 \\
recovery & - & 36 & $81 \cdot 8$ \\
HBsAg carrier & + & 0 & 0 \\
state & - & 2 & 4.6 \\
\hline
\end{tabular}

Table 2 Appearance of anti-e in 44 cases of acute hepatitis $B$

\begin{tabular}{llll}
\hline Outcome & e Antigen & $\begin{array}{l}\text { Number with } \\
\text { anti-e }\end{array}$ & $\begin{array}{l}\text { Time of first } \\
\text { appearance after } \\
\text { onset of jaundice }\end{array}$ \\
\hline $\begin{array}{l}\text { Complete } \\
\text { recovery }\end{array}$ & + & 1 & 3 weeks \\
HBsAg carrier & + & 1 & 4 weeks \\
state & - & 0 & 7 months \\
\hline
\end{tabular}

Table 3 Detection of e antigen related to the sampling date

\begin{tabular}{lll}
\hline e Antigen & Number & $\begin{array}{l}\text { Number taken within one week of } \\
\text { onset of jaundice }\end{array}$ \\
\hline+ & 6 & $6(100 \%)$ \\
- & 38 & 9 \\
Total & 44 & 15 \\
\hline
\end{tabular}

Table 4 Presence of $e$ antigen related to duration of $\mathrm{HBs}$ antigenaemia

\begin{tabular}{lcl}
\hline e Antigen & Number & $\begin{array}{l}\text { Average duration of } \mathrm{HBs} \\
\text { antigenaemia }\end{array}$ \\
\hline+ & 6 & $\begin{array}{l}8.6 \text { weeks }(2-15) \\
-\end{array}$ \\
\hline
\end{tabular}

\section{Discussion}

Other studies (Eleftheriou et al., 1975; El Sheikh et al., 1975; Feinman et al., 1975; Nordenfelt et al., 1975; Vogten et al., 1976) have indicated that e antigen is strongly associated with carriers of HBsAg who have chronic liver disease. Recently, Norkrans et al. (1976) have looked for e antigen in acute hepatitis and found $e$ antigen present in the acute phase of illness in $29 \%$ of cases. In their study, only patients admitted to hospital within 10 days of onset of illness were studied. In the present report e antigen was found in $13.6 \%$ of cases of acute hepatitis. However, this percentage is increased to $40 \%$ if we consider only those patients whose first serum specimen was taken within the first week of jaundice (Table 3). e Antigen is found very early in the acute phase and disappears rapidly. However, with more sensitive techniques than ID, e may be detected in far more, possibly all, cases of acute hepatitis B. It is possible that, in individuals who recover, this short period when $e$ is detectable may be the period of infectivity. It is also possible that with a more sensitive test anti-e might be detected more frequently. It seems to appear just as the $\mathrm{HBsAg}$ is disappearing from the serum. In one case anti-e was detected in the first HBsAg negative specimen three weeks after the onset of jaundice. By immune electron microscopy this serum was seen to clump Dane and long particles but not the small round particles of HBsAg (B. J. Cohen, personal communication).

Our observations, therefore, are contrary to the findings of Norkrans et al. (1976) since in this series of cases the presence of e antigen was not related to any prolongation of HBs antigenaemia, nor was there any evidence that its presence indicated an increased risk of chronic liver disease.

\section{References}

El Sheikh, N., Woolf, I. L., Galbraith, R. M., Eddleston, A. L. W. F., Dymock, I. W., and Williams, R. (1975). e Antigen-antibody system as indicator of liver damage in patients with hepatitis-B antigen. British Medical Journul, 4, 252-253.

Eleftheriou, N., Thomas, H. C., Heathcote, J., and Sherlock, S. (1975). Incidence and clinical significance of e antigen and antibody in acute and chronic liver disease. Lancet, 2, 1171-1173.

Feinman, S. V., Berris, B., Sinclair, J. C., Wrobel, D. M., Murphy, B. L., and Maynard, J. E. (1975). e Antigen and anti-e in HBsAg carriers. Lancet, 2, 1173-1174.

Magnius, L. O., and Espmark, J. A. (1972). New specificities in Australia antigen positive sera distinct from the Le Bouvier determinants. Journal of Immunology, 109, 1017-1021.

Nielsen, J. O., Dietrichson, O., and Juhl, E. (1974). Incidence and meaning of the " $\mathrm{e}$ " determinant among hepatitis-B-antigen positive patients with acute and chronic liver diseases. Lancet, 2, 913-915.

Nordenfelt, E., Lindholm, T., and Henrikson, H. (1975). The relationship between hepatitis $\mathrm{B}$ antigen, e-antigen and liver-pathology in patients treated with dialysis. Scandinavian Journal of Urology and Nephrology, 9, 277281. 
Norkrans, G., Magnius, L., and Iwarson, S. (1976). e Antigen in acute hepatitis B. British Medical Journal, 1, 740-742.

Vogten, A. J. M., Schalm, S. W., Summerskill, W. H. J., Smith, J. L., Gitnick, G. L., Murphy, B. L., and
Maynard, J. E. (1976). Behaviour of e antigen and antibody during chronic active liver disease. Relation to HB antigen-antibody system and prognosis. Lancet, 2, 126128. 